\title{
IJMA' SEBAGAI PENYATUAN PERBEDAAN AWAL BULAN QAMARIAH
}

\begin{abstract}
Ahmad Fadholi*
Abstract

The teachings of Islam can be understood, because Islam brought by Prophet Muhammad pbuh. at 14 centuries ago, who was sent to convey Islamic teachings with the holy book, al-Qur'an as the principal teachings of Islam. While the second source is as-Sunnah. Both of them, al-Quran and as-Sunnah, are the principal source of Islamic teachings. Along with the times increasingly complex, the problems in people's lives are more and more undiscovered in these two sources. it is necessary for an ijtihad to finish its problems by way of ijma 'as a method of solving problems of religion. Ijma 'itself is an agreement of the mujtahid at some time after Prophet Muhammad on a syar'i law about a particular event. Events of the law faced by Muslims did'n stop by the death of the Prophet Muhammad pbuh. This problem, both in types and quality, is always developed according with evolution of time. Therefore, alternatives taken to determine the laws of any event are through ijtihad and make decisions together. That joint decision is called ijma ' and is the third argument agreed by sholars to be sources of law. Then by agreement as a third source of law, it have power in the Islamic legal system. The power of ijma' has been suggested by the Prophet in a hadith " $L a$ tajtami'u ummati' ala al-dhallah".
\end{abstract}

Keywords: Ijma, firts moon, sunna 


\section{A. Pendahuluan}

Ajaran Islam yang dibawa oleh nabi Muhammad saw. bersifat universal, tidak terbatas oleh waktu dan tempat tertentu. Ajaran Islam berlaku seluruh manusia dimana pun mereka berada. Keuniversalan ajaran Islam membawa konsekwensi komperhensifnya kandungan ajarannya dalam menjawab setiap permasalahan yang muncul dari waktu ke waktu. Sehingga setiap perbuatan dan aktifitas umat manusia, baik yang sesudah sedang maupun yang akan terjadi telah tercover dalam kandungan ajaran Islam.

Ajaran Islam bisa dipahami, sebab Islam dibawa oleh nabi Muhammad saw. 14 abad silam, yang diutus untuk menyampaikan ajaran Islam dengan membawa kitab suci al-Qur'an sebagai pokok ajaran agama Islam. Sedangkan sumber yang kedua adalah as-sunnah yang merupakan segala tindakan, perkataan, perbuatan. Keduannya, al-Qur'an dan as-sunnah, merupakan sumber pokok ajaran Islam.

Seiring dengan perkembangan zaman, yang semakin kompleks maka permasalahan dalam kehidupan manusia sebakin banyak yang belum ditemukan dalam dua sumber tersebut, untuk itu diperlukan adanya sebuah ijtihad untuk menyesaikan permasalahan, dengan cara melakukan ijma' sebagai metode dalam memecahkan permasalahan agama.

Ijma' sendiri merupakan sebuah kesepakatan para mujtahid pada suatu masa sepeninggalan nabi Muhammad saw. Tentang suatu hukum syar'i mengenai suatu peristiwa tertentu. Peristiwa atas hukum yang dihadapi umat Islam tidaklah terhenti dengan meninggalnya nabi Muhammad saw. Masalah ini baik jenis maupun kualitasnya, selalu berkembang sesuai perkembangan sesuai perkembangan masa.

Karena itu alternatif yang di tempuh untuk menentukan suatu hukum dari suatu peristiwa, yaitu melalui ijtihad dan mengambil keputusan secara bersama. Keputusan bersama itu yang disebut ijma' dan sebagai dalil ketiga yang disepakati ulama untuk menjadi sumber hukum.

Maka dengan disepakati sebagai sumber hukum ketiga berarti mempunyai kekuatan dalam sistem hukum Islam. Kekuatan ijma' 
telah diisyaratkan nabi dalam sebuah hadits "La tajtami'u ummati 'ala al-dhallah".

\section{B. Pembahasan.}

\section{Konsep Ijma'}

Ijma' menurut ulama usul Fiqh adalah kesepakatan semua mujtahid pada suatu masa setelah wafatnya Rasul atas hukum syara' mengenai suatu kejadian ${ }^{1}$

Ijma' secara etimologi diartiakan kesepakatan (al-ittifaq) atau "konsensus" sebagaimana firman Allah dalam surat Yunuf [12]; 15.

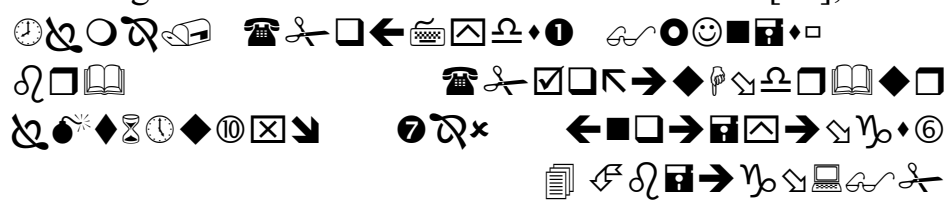

Artinya; "Maka tatkala mereka membawanya dan sepakat memasukkannya ke dasar sumur (lalu mereka masukkan dia), dan (di waktu dia sudah dalam sumur) ........."

Selain itu, Ijma' juga mempunyai arti ketetapan hati untuk melakukan sesuatu (al-'azmi) sebagaimana yang disebutkan dalam surat Yunus [10]; 71 .

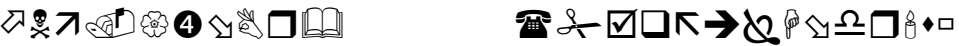

$$
\begin{aligned}
& \text { « }
\end{aligned}
$$

Artinya; "Karena itu bulatkanlah keputusanmu dan (kumpulkanlah) sekutu-sekutumu”...

Ijma' secara terminologi, ada beberapa rumusan Ijma' yang dikemukakan para ulama diantaranya; Imam Ghozali mendefinisikan Ijma' adalah "Kesepakatan umat Muhammad saw secara khusus atas suatu masalah agama" rumusan Imam Ghozali memberikan batasan tentang Ijma' hanya pada umat Muhammad saw. Yaitu umat Islam termasuk orang awam. Menurut Imam Ghozali Ijma' pada masa Rasul

${ }^{1}$ Abdul Wahhab Khallaf, 2003, Ilmu Ushul Fiqh, Jakarta: Pustaka Amani, 
tidak diperlukan sebab keberadaan Rasul sebagai syara' (sumber hukum) tidak memerlukan Ijma'.

Rumusan ini menurut al-Amidi mengutip pandangan imam Syafi'i yang menyatakan bahwa Ijma' harus dilakukan dan dihasilkan oleh seluruh umat Islam, karena suatu pendapat yang dapat terhindar dari suatu kesalahan hanya apabila disepakati oleh seluruh umat. Selanjutnya al- Amidi merumuskan Ijma' "kesepakatan sejumlah ahlul hall wal aqdi kesepakatan kelompok oleh umat Muhammad saw pada suatu masa terhadap suatu hukum dari satu peristiwa atau kasus".

Al-Amidi menunjukan bahwa yang terlibat dalam Ijma' tidak semua orang, melainkan orang-orang tertentu dengan sebutan ahlul hall wal aqdi yang bertanggung jawab langsung terhadap umat, maka orang awam tidak di perhitungkan dalam proses Ijma'.2. Sedangkan Wabah al-Zuhaili merumuskan Ijma' "kesepakatan mujtahid dari umat Muhammad saw. Pada suatu masa setelah wafatnya nabi terdapat suatu hukum syara'.

Ijma' menurut jumhur ulama sebagaimana yang dikutip oleh Wahbah al-Zuhaili merumuskan ijma' "kesepakatan para mujtahid dari umat Muhammad saw. pada suatu masa, setelah wafatnya Rasulullah saw. terhadap hukum syara'. Sedangkan Abu Zahrah menambahkan pengertian Ijma' di akhir "yang bersifat alamiyah" bahwa Ijma' mengandung pengertian bahwa hanya membahas permasalahan atau persoalan yang berkaitan dengan furu' (alamiyah praktis).

Abdul Wahab Khallaf mengatakan apabila seuatu peristiwa yang pada saat terjadinya diketahui oleh semua mujtahid kemudian mereka sepakat memutuskan hukum atas peristiwa tersebut. Kesepakatan mereka dijadikan dalil bahwa hukum itu adalah hukum syara' atas suatu kejadian. ${ }^{3}$ Sedangkan Ijma' menurut Muhammad

\footnotetext{
${ }^{2}$ Syarifuddin, 1997, Ushul Fiqh, Jilid 1, Jakarta; Logos, 113

${ }^{3}$ Abdul Wahab Khallaf, Op.Cit, 54)
} 
Khudhari Biek, adalah suatu produk hukum atas hasil kesepakatan para mujtahidin dari suatu umat dalam satu masa. ${ }^{4}$

Dari beberapa definisi diatas bahwa Ijma' tersebut hanya dilakukan kesepakatan oleh semua mujtahid ${ }^{5}$ dari Ijma' umat Muhammad saw $^{6}$ dalam suatu masa setelah nabi wafat terhadap hukum syara'. Karena selama nabi masih hidup seluruh permasalahan yang timbul bisa langsung ditanyakan kepada nabi sehingga tidak diperlukan Ijma'.

Maka dari sini dapat ditarik pemahaman bahwa Ijma' merupakan; pertama kesepakatan seluruh mujtahid dari Ijma' umat Muhammad. Kedua Ijma' dilakukan dalam suatu masa setelah nabi wafat. Ketiga berkaitan dengan hukum-hukum syara'. ${ }^{7}$ Hukum syara' yang dimaksud mengandung arti bahwa kesepakatan itu hanya terbatas pada masalah amaliyah dan tidak sampai masalah aqidah. Maka dalam hal ini kesepakatan itu bisa berlakau terhadap hukum yang masalahnya yang belum terjadi baik dalam hukum isbat atau hukum nafi.

\footnotetext{
${ }^{4}$ Khudhari Biek, 2007, Ushul Fiqh, Jakarta: Pustaka Amani, 606.
}

${ }^{5}$ Mujtahid adalah orang yang bersungguh-sungguh. Dalam disiplin ilmu ushul fikih, seorang mujtahid dikenal sebagai tenaga profesional yang mampu menelurkan produk-produk hukum. Dengan keahlian serta ketekunan yang ia miliki, ia mampu menjawab seluk beluk persoalan syara'. Melalui metode istinbath, ia menggali hukum-hukum yang ada dalam al-Quran dan hadis.

Menurut al-Ghazali mujtahid adalah seorang yang fatwa-fatwanya bisa diterima. Seseorang baru bisa dikatakan sebagai mujtahid jika ia mempunyai spesialisasi dalam satu bidang ilmu tertentu. Oleh karena itu tidak salah kalau seorang yang melakukan ijtihad menyandang gelar mujtahid, faqih, ahlu ar-ra'yi dan lain sebagainya.

${ }^{6}$ Ijma' hanya para mujtahid umat muhammad dan sekaligus mengecualikan kesepakatan para mujtahid yang bukan dari umat Muhammad.

${ }^{7}$ Ahmad Saebani, 2008, Ilmu Usul Fiqh, Bandung: CV Pustaka Setia,hal. 
Adapun rukun Ijma' dalam definisi di atas adalah adanya kesepakatan para mujtahid kaum muslimin dalam suatu masa atas hukum syara' kesepakatan' itu dapat dikelompokan menjadi empat hal:

1. Tidak cukup Ijma' dikeluarkan oleh seorang mujtahid apabila keberadaanya hanya seorang (mujtahid) saja di suatu masa. Karena kesepakatan dilakukan lebih dari satu orang, pendapatnya disepakati antara satu dengan yang lain.

2. Adanya kesepakatan sesama para mujtahid atas hukum syara' dalam suatu masalah, dengan melihat negeri, jenis dan kelompok mereka. Andai yang disepakati atas hukum syara' hanya para mujtahid haramain, para mujtahid Irak saja, Hijaz saja, mujtahid ahlu Sunnah, Mujtahid ahli Syiah, maka secara syara' kesepakatan khusus ini tidak disebut Ijma'. Karena Ijma' tidak terbentuk kecuali dengan kesepakatan umum dari seluruh mujtahid di dunia Islam dalam suatu masa.

3. Hendaknya kesepakatan mereka dimulai setiap pendapat salah seorang mereka dengan pendapat yang jelas apakah dengan dalam bentuk perkataan, fatwa atau perbuatan.

4. Kesepakatan itu terwujudkan atas hukum kepada semua para mujtahid. Jika sebagian besar mereka sepakat maka tidak membatalkan kespekatan yang 'banyak' secara Ijma' sekalipun jumlah yang berbeda sedikit dan jumlah yang sepakat lebih banyak maka tidak menjadikan kesepakatan yang banyak itu hujjah syar'i yang pasti dan mengikat. ${ }^{8}$

Di samping kelima rukun diatas, Jumhur Ulama ushul fiqh, mengemukakan pula syarat-syarat ijma', yaitu :

1. Yang melakukan ijma' tersebut adalah orang-orang yang memenuhi persyaratan ijtihad

2. Kesepakatan itu muncul dari para mujtahid yang bersifat adil (berpendirian kuat terhadap agamanya).

3. Para mujtahid yang terlibat adalah yang berusaha menghindarkan diri dari ucapan atau perbuatan bid'ah.

\footnotetext{
${ }^{8}$ Wahhab Khallaf, 2003, Op.Cit, hal. 45-46).
} 
Ketiga syarat ini disepakati oleh seluruh ulama ushul fiqh. Ada juga syarat lain, tetapi tidak disepakati oleh para ulama, diantaranya : (1) para mujtahid itu adalah sahabat, (2) Mujtahid itu kerabat Rasulullah saw.; apabila memenuhi dua syarat ini, para ulama ushul fiqh menyebutnya dengan ijma' sahabat, (3) Mujtahid itu adalah ulama madinah, (4) Hukum yang disepakati itu tidak ada yang membantahnya sampai wafatnya seluruh mujtahid yang menyepakatinya, (5) tidak terdapat hukum ijma' sebelumnya yang berkaitan dengan masalah yang sama. ${ }^{9}$

\section{Kehujjahan Ijma'}

Jumhur ulama berpendapat bahwa ijma' dapat menjadi dalil hukum (hujjah) selagi memenuhi rukun-rukun ijma'. Dalam kondisi seperti tersebut, ijma' menjadi hujjah yang 'qath' $i$ (pasti), wajib diamalkan dan tidak boleh diingkari, sehingga jika ada orang yang mengingkari maka ia dianggap kafir. Dengan begitu, ijma' juga dapat menjadi dasar penetapan fatwa.

Di samping itu, permasalahan yang telah ditetapkan hukumnya melalui ijma'tidak boleh lagi menjadi pembahasan ulama generasi berikutnya, karena hukum yang ditetapkan melalui ijma, merupakan hukum syara' yang 'qath' $i$ dan menempati urutan ketiga sebagai dalil syara' setelah alqur'an dan assunah. Alsan yang disepakati oleh Jumhur Ulama sebagaimana firman Allah swt.

1. Surat An-Nisa' [04]; 59

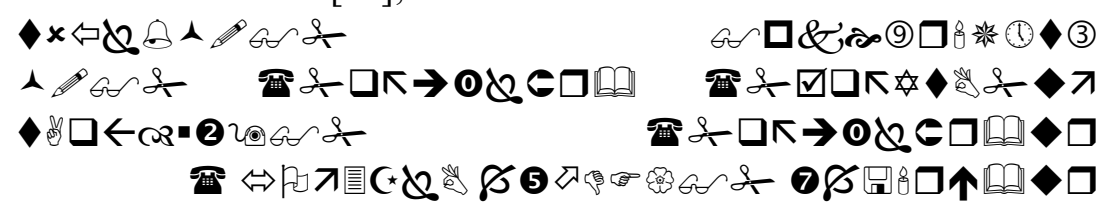

Artinya: Hai orang-orang yang beriman, taatilah Allah dan taatilah Rasul (nya), dan ulil amri di antara kamu....Qs. an-Nisa' [4]; 59

\footnotetext{
${ }^{9}$ Makruf Amin, 2008, Fatwa dalam Sistem Hukum Islam, Jakarta: Elsas,
} 
Menurut Jumhur Ulama, lafazh uli al-amr dalam ayat itu bersifat umum, mencakup para pemimpin di bidang agama (para mujtahid dan pemberi fatwa) dan pemimpin masyarakat, negara dan perangkatnya, Ibnu 'Abbas menafsirkan dengan para ulama.

Lafaz al-amri pada ayat ini mengandung dua pengertian yaitu, al-amr berhubungan dengan agama dan al-amr yang berhubungan dengan dunia. Ulil amri yang bersifat agama itu adalah para mujtahid dan para ahli fatwa, ulil amri yang bersifat duniawi adalah para kepala agama. Apabila telah sepakat ulil amri tentang suatu hukum wajib mengikuti dan melaksanakannya. ${ }^{10}$

2. Surat al-Baqarah [2]; 143

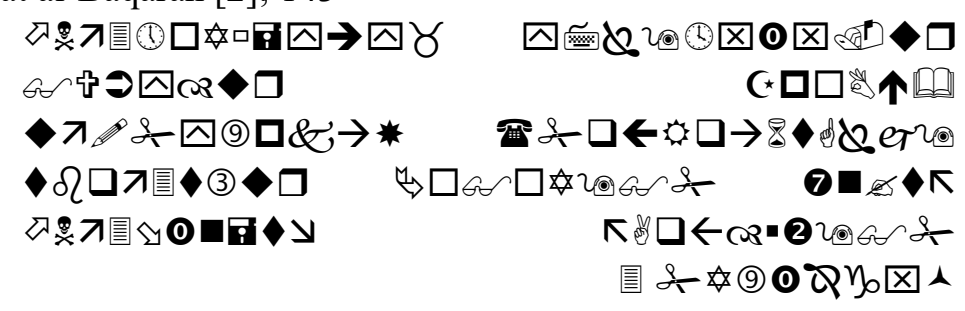

Artinya: Dan demikian (pula) kami Telah menjadikan kamu (umat Islam), umat yang adil dan pilihan ${ }^{11}$ agar kamu menjadi saksi atas (perbuatan) manusia dan agar Rasul (Muhammad) menjadi saksi atas (perbuatan) kamu...... Qs. al-Baqarah [2] 143

3. Surat al- Imran [4]; 110

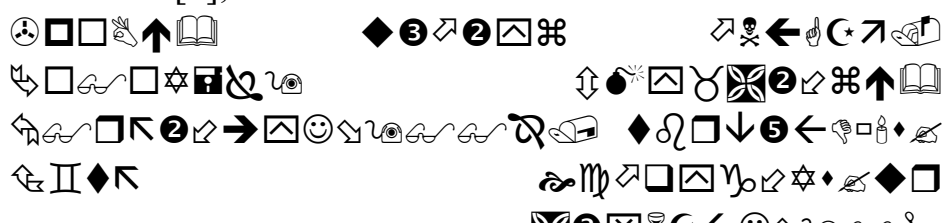

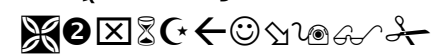

Artinya: Kamu adalah umat yang terbaik yang dilahirkan untuk manusia, menyuruh kepada yang ma'ruf, dan mencegah dari yang munkar...... Qs. al- Imran [4]; 110.

\footnotetext{
${ }^{10}$ Wahhab Khallaf, 2003, Op.Cit. hal. 56-57
}

11 umat Islam dijadikan umat yang adil dan pilihan, Karena mereka akan menjadi saksi atas perbuatan orang yang menyimpang dari kebenaran baik di dunia maupun di akhirat. 
4. Surat al-Syura [42]; 10.

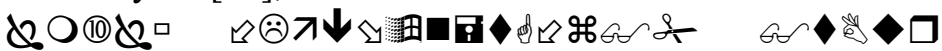

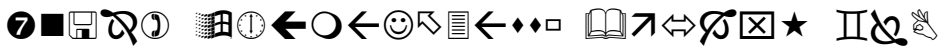

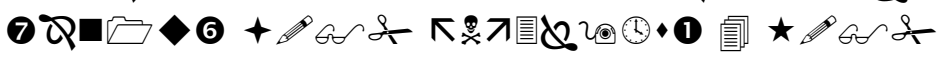

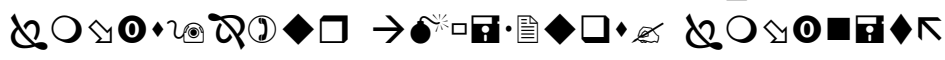

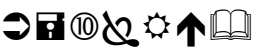

Artinya; Tentang sesuatu apapun kamu berselisih, Maka putusannya (terserah) kepada Allah. (yang mempunyai sifat-sifat demikian) Itulah Allah Tuhanku. kepada-Nya lah Aku bertawakkal dan kepada-Nyalah Aku kembali. Qs. al-Syura [42]; 10.

5. Surat an-Nisa' [42]; 10.

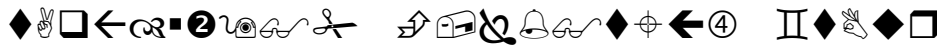

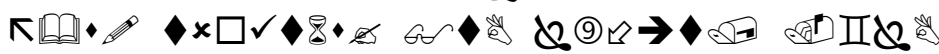

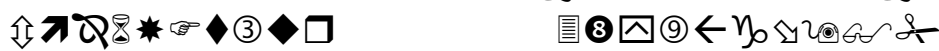

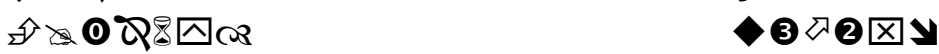

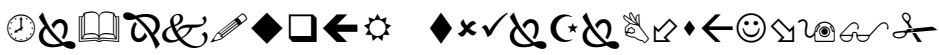

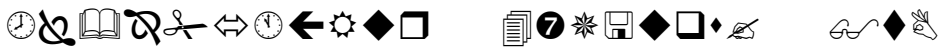

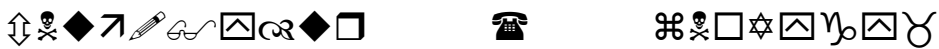

$$
\begin{aligned}
& \text { \& (1) } 32 \text { 负 (1) है }
\end{aligned}
$$

Artinya: Dan barangsiapa yang menentang Rasul sesudah jelas kebenaran baginya, dan mengikuti jalan yang bukan jalan orang-orang mukmin, kami biarkan ia leluasa terhadap kesesatan yang Telah dikuasainya itu ${ }^{12}$ dan kami masukkan ia ke dalam Jahannam, dan Jahannam itu seburuk-buruk tempat kembali. Qs. an-Nisa' [4]; 115

6. Surat Ali-Imran [03]; 103

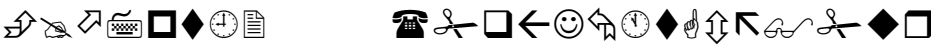

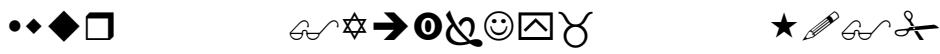

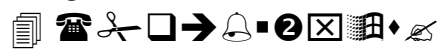

Artinya; Dan berpeganglah kamu semuanya kepada tali (agama) Allah, dan janganlah kamu bercerai berai, ...Qs. ali -Imran [03]; 103

\footnotetext{
${ }^{12}$ Allah biarkan mereka bergelimang dalam kesesatan.
} 
Menurut al-Ghazali terdapat banyak riwayat yang menguatkan bahwa ijma' bisa dijadikan hujjah. Dalam hadits-hadits tersebut dinyatakan bahwa umat Islam tidak mungkin bersepakat dalam hal yang salah. Pendapat ini masyhur di kalangan sahabat, Di antaranya Umar bin Khattab, Ibnu Mas'ud, Abu Hurairah, Anas bin Malik dan yang lainnya. Walaupun secara redaksional satu hadits berbeda dengan hadits yang lain, tetapi mengandung makna yang sama. Dengan kata lain, hadits - hadits tersebut adalah mutawatir dalam maknanya walaupun ahad dalam lafazhnya. Diantara rumusan hadits tersebut adalah;

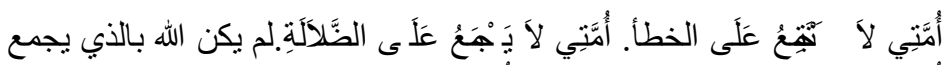

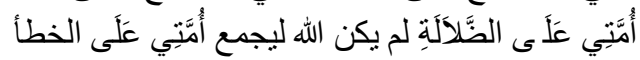

Artinya: Umatku tidak ada sepakat untuk melakukan kesalahan.

Umatku tidak akan sepakat melakukan kesesatan. Allah tidak akan membuat umatku sepakat untuk melakukan kesesatan. Allah tidak akan membuat umat sepakat untuk melakukan kesalahan.

Dalam hadist ini menjelaskan bahwa umat dalam kedudukanya sebagai umat yang sama-sama sepakat tentang sesuatu tidak mungkin salah. Maka ijma' itu terpelihara dari kesalahan, sehingga keputusanya sebagai hukum yang mengikat umat Islam. ${ }^{13}$

\section{Macam-Macam Ijma'}

Dilihat dan segi cara terjadinya kesepakatan terhadap hukum syara, para ulama membagi ijma' menjadi dua ;

1. Ijma' Sharih/Nuthqi:

Yaitu kesepakatan para mujtahid baik melalui pendapat maupun melalui perbuatan terhadap hukum masalah tertentu. Kesepakatan itu dilakukan dalam sidang ijma' semuanya setelah

${ }^{13}$ Syaifuddin, Amir.1997, Op.Cit. hal. 120 
masing-masing mujtahid mengemukakan pandangannya terhadap masalah yang dibahas. ${ }^{14}$

Ijma' sepeti ini sangatlah langka terjadi, apalagi bila dilakukan kesepakatan itu dalam satu majelis atau pertemuan yang dihadiri seluruh mujtahid pada masa tertentu. Karena itu sebagian ulama berpendapat bahwa ijma sharih hanya mungkin terjadi pada masa sahabat, sebab pada waktu itu jumlah mujtahid masih terbatas dan tempat tinggal masih relatif berdekatan sehingga tidak sulit untuk berhubungan atau menyampaikan pendapatnya.

Namun demikian menurut sebagian besar ulama, apabila ijma' ini berlangsung dan menghasilkan suatu hukum, maka bisa dijadikan hujjah dan kekuatan hukum bersifat qath'I (pasti), sehingga mempunya kekuatan yang mengikat dan tidak boleh siapapun pada masa itu untuk menyanggahnya dan para mujtahid yang telah mengemukakan pendapatnya tidak boleh mencabut yang telah dikemukakanya. ${ }^{15}$

\section{Ijma' Sukuti}

Yaitu: Pendapat sebagian mujtahid pada suatu zaman tentang hukum suatu masalah dan tersebar luas, sedangkan sebagian mujtahid lainya hanyalah diam saja setelah diteliti pandapat mujtahid yang dikemukakan, tanpa ada komentar penolakan tentang pendapat tersebut. ${ }^{16}$

Dalam persoalan ijma' sukuti terdapat perbedaan pendapat di kalangan ulama usul fiqh, sebagaian mereka tidak memandang ijma' sukuti sebagai hujjah bahwa tidak menyatakan sebagai ijma' diantara pengikunya Imam Malik dan Imam Syafi' ${ }^{17}{ }^{17}$

${ }^{14}$ Alaiddin Koto, 2004, Ilmu Fiqh dan Ushul Fiqh, Jakarta: PT Rajagrafindo Persada, hal. 82)

${ }^{15}$ Syaifuddin, 1997, Op.Cit, hal. 135)

${ }^{16} \mathrm{Ibid}$

${ }^{17}$ Rahmat Syafii, 1999, Ilmu Ushul Figh, Bandung: CV Pustaka Setia. Hal. 
Sedangkan mereka yang sepakat bahwa ijma' sukuti dijadikan hujjah yang qath'I diantara golongan ulama Hanafiyah dan Imam Ahmad. sedangkan pendapat yang lain bahawa ijma' sukuti bisa dijadikan ijma' generasi mujtahid yang menyepakati hukum tersebut setelah habis apabila mujtahid lain bersikap diam saja terhadap hukum yang disepakati sebagai mujtahid sampai mereka wafat, maka ada mujtahid yang membantah hukum tersebut tidak ada lagi, pandangan ini dikemukakan oleh Abd Ali al-jubba'I seorang tokoh mu'tazilah.

Maka dari sinilah Muhammad Abu Zahrah mengatakan alasan yang dikemukakan oleh ulama Hanafiyah dan Ahmad hanbali adalah

1. Diamya ulama setelah mengetahui satu hukum hasil ijtihad yang dikemukakan oleh seorang mujtahid adalah setelah mempelajari dan menganalisis hasil ijtihad itu dari berbagi segi.

2. Tidak dapat diterima jika para ahli fatwa diam saja ketika mendengar adanya fatwa ulama lain. karena sesuai dengan kebiasaan di lingkungan ulama fatwa, jika ada seorang ulama mengemukakan pendapat tentang hukum suatu kasus, maka para ulama menanggapinya jika fatwa itu dianggap tidak benar, sebab apabila ulama itu diam saja maka sikap tersebut dianggap setuju. $^{18}$

\section{Ijma' dan Permasalahan Hisab Rukyat}

Dalam permasalah penentuan awal bulan Ramadhan dan Syawal, pijakan yang digunakan adalah ayat-ayat al-Qur'an dan hadits-hadits hisab rukyah. al-Qur'an tidak menjelaskan secara terperinci bagaimana cara menentukan awal bulan Ramadhan, Syawal, Dzulhijjah dan bulan yang lainya.

Penentuan tersebut dijelaskan dalam hadits-hadits nabi. Haditshadits tersebut merupakan petunjuk Rasulullah dalam menentukan awal Ramadhan dan Syawal karena kaitannya dengan kewajiban puasa. Maka akibat perbedaan penafsiran dan pemahaman terhadap hadits yang berkaitan dengan penentapan awal bulan yaitu:

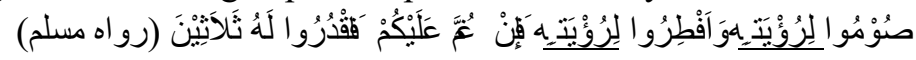

${ }^{18}$ Makruf Amin, 2008, Op.Cit, hal. 100-101 
Artinya; Berpuasalah karena melihat hilal, dan berbukalah karena melihatnya. Maka jika ia tertutup awan, maka perkirakanlah ia tiga puluh". (H.R. Muslim).

Huruf "lam" pada kata "li ru'yatih" dalam matan hadis di atas, menurut Al-Ùaybi "li al-waqti, li al-tawqit" dan Ibn Daqiq al-'Id "li al-ta'qit" yang menunjukkan waktu secara majaz; bukanlah lam li alta'lil yang menunjukkan sebab. Sehingga perintah dalam hadis tersebut berarti: berniatlah berpuasa pada saat hilal sudah terlihat atau dengan kata lain berpuasa sesudah hilal terlihat. Sebaliknya, jika lam li al-ta 'lil maka perintah tersebut lanjut Ibn Daqiq al-'Id berarti, berpuasa sebelum hilal terlihat ${ }^{19}$

Dalam naskah lain, kelompok rukyah berpendapat yang dimaksud dengan kata "rukyat" adalah melihat hilal secara fisik (rukyat bil fi'li). Pendapat ini didasarkan kepada alasan bahwa Rasulullah dan para sahabat selalu melihat hilal untuk menentukan awal dan akhir Ramadan. Sedangkan Pendapat kedua, yaitu kelompok hisab menafsirkan "rukyat" dengan rukyat bil 'ilmi (melihat dengan ilmu).

Perbedaan tersebut dikhususkan pada penafsiran kata رؤية. Ada yang menafsirkan kata rukyat tersebut sebagai perhitungan karena menganggap kata rukyat berasal dari kata رأى- يرى yang berarti berpendapat. Disini mereka mengatakan bahwa yang dimaksud dengan berpendapat adalah proses kerja otak dengan melakukan perhitungan. Di pihak lain ada yang mengatakan bahwa kata rukyat diartikan sebagai melihat dengan mata kepala.

Memang, dalam bahasa Arab satu kata bisa memiliki arti yang banyak dan bermacam-macam. Sebagai halnya dalam fiqh, kata quru bisa berati suci bisa juga berarti haid. Perbedaan makna ini jelas akan menimbulkan perbedaan penafsiran pula. Dari sinilah timbul adanya perbedaan yang pada dasarnya didominasi oleh dua kekuatan besar yaitu Hisab dan Rukyat.

${ }^{19}$ Muhammad ibn 'Ali al-Sawkani. 1973, Nayl al-Awtar Sarh Muntaqa alAkbar, Bayrut: Dar al-Jayl. hal.64 
Sebenarnya, asal dari kedua kata tersebut adalah sama yaitu رأى - رؤية Kata tersebut merupakan bentuk isim mashdar dari kata رأى kata dan tashrifnya memiliki banyak arti, antara lain:

Dengan mashdar رؤية berati أبصر, yaitu melihat dengan mata kepala. Berarti demikian jika obyeknya merupakan sesuatu yang bisa dilihat dengan mata kepala. Sebagaimana yang terdapat dalam surat Al-An'am [6]; 76-78

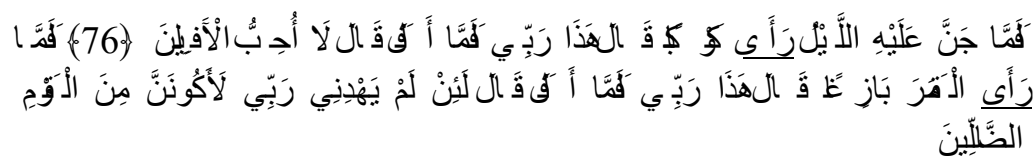

Artinya; Ketika malam Telah gelap, dia melihat sebuah bintang (lalu) dia berkata: "Inilah Tuhanku", tetapi tatkala bintang itu tenggelam dia berkata: "Saya tidak suka kepada yang tenggelam." Kemudian tatkala dia melihat bulan terbit dia berkata: "Inilah Tuhanku". tetapi setelah bulan itu terbenam, dia berkata: "Sesungguhnya jika Tuhanku tidak memberi petunjuk kepadaku, Pastilah Aku termasuk orang yang sesat." Kemudian tatkala ia melihat matahari terbit, dia berkata: "Inilah Tuhanku, Ini yang lebih besar". Maka tatkala matahari itu terbenam, dia berkata: "Hai kaumku, Sesungguhnya Aku berlepas diri dari apa yang kamu persekutukan. QS. Al-An'am [6]; 76-78

Kata رأى أى ألثمس dan روكبا memiliki arti melihat karena obyek keduanya (matahari dan bintang) merupakan benda yang dapat dilihat dengan mata kepala.

1. Dengan mashdar رأي memiliki arti علم / أدرك, artinya mengerti, memahami, memperhatikan, berpendapat, dan melihat dengan akal pikiran. Dengan arti demikian maka jelas jika benda yang menjadi obyek kata tersebut adalah benda abstrak, tidak dapat dilihat oleh mata kepala. Hal tersebut senada dengan firman Allah SWT:

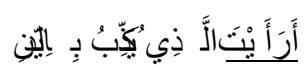

Artinya; Tahukah kamu (orang) yang mendustakan agama?.. QS. AlMaa'uun [107] : 1 
Mendustakan agama merupakan obyek yang abstrak. Hal itu tidak bisa dilihat dengan mata kepala.

2. Dengan mashdar راي juga memiliki arti ظن / حسب , artinya mengira, menduga, yakin, dan ada yang mengatakan melihat dengan hati. Dalam bahasa Arab, kat tersebut ditetapkan sebagai fi'il yang membutuhkan dua buah obyek (maf'ul bihi), sebagaimana terdapat dalam Firman Allah:

$$
\text { إِنَّهُمْ َْرَوْنَدَدُ بَعِيدًا }
$$

Artinya; Sesungguhnya mereka memandang siksaaan itu jauh (mustahil). QS. Al-Ma'arij [70] : 6

Dari pengertian tentang kata رؤية tersebut muncullah madzhab Hisab dan Rukyat yang berkembang di masyarakat Indonesia.

حسابا - يحسب-حسب Kata Hisab berasal dari Bahasa Arab yaitu yang artinya menghitung. Dalam Bahasa Inggris kata ini disebut Arithmatic yaitu ilmu pengetahuan yang membahas tentang seluk beluk perhitungan.

Kata Hisab dalam al Qur'an dapat mempunyai beberapa arti antara lain:

1. Perhitungan, sebagaimana Firman Allah dalam Qs. an Nisa' [3] ayat 87

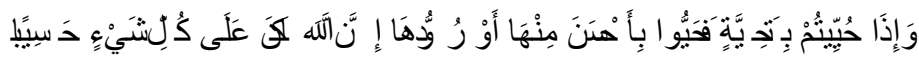
Artinya; Apabila kamu dihormati dengan suatu penghormatan, balaslah penghormatan itu dengan yang lebih baik, atau balaslah (dengan serupa). Sesungguhnya Allah selalu membuat perhitungan atas segala sesuatu.. Qs. al Nisa': [3]; 87

2. Memeriksa, sebagaimana Firman Allah dalam Qs. al Insyiqoq [84] ayat 8

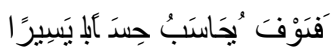

Artinya; Maka dia akan diperiksa dengan pemeriksaan yang mudah". Qs. al Insyiqoq: [84]; 8.

3. Pertanggungjawaban, sebagaimana Firman Allah dalam Qs. al An'am [6] ayat 69 


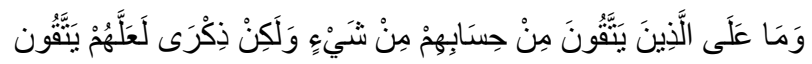

Artinya; Dan tidak ada pertanggungjawaban sedikitpun atas orangorang yang bertaqwa terhadap dosa mereka, akan tetapi kewajiban mereka telah mengingatkan mereka agar mereka bertaqwa.. Qs al An'am: [6]; 69

Dalam Ilmu Falak Hisab artinya menghitung perjalanan matahari dan bulan pada bola langit. Dengan hisab orang dapat mengetahui dan memperkirakan kapan awal dan akhir bulan Qamariyah tanpa harus melihat hilal. Madzhab hisab melandaskan pada firman Allah swt :

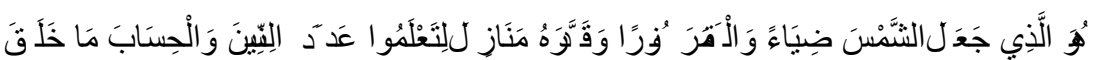

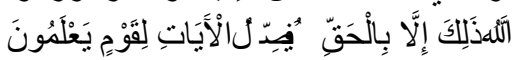

Artinya; Dialah yang menjadikan matahari bersinar, bulan bersinar dan ditetapkannya manzilah manzilah bagi perjalanan bulan itu, supaya kamu mengetahui bilangan tahun dan diperhitungkan. QS. Yunus [10] : 5.

Kemungkinan posisi bulan dan matahari dapat dihitung, mengingat kedua benda tersebut, sebagai disebut dalam al-Quran masing-masing memiliki orbit (falak) dan periode peredaran tertentu dan teratur, apalagi bulan memiliki fase-fase penampakan (manzilah) yang secara jelas terlihat dari bumi.

Dalam surat Al-Baqarah [2] ayat 185.

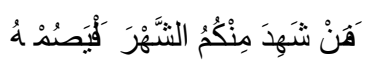

Artinya; Karena itu, barangsiapa di antara kamu hadir (di negeri tempat tinggalnya) di bulan itu, maka hendaklah ia berpuasa pada bulan itu. Qs. Al-Baqarah [2]; 185

Kata "Sahida" dalam ayat ini ditafsirkan oleh sejumlah ulama, sebagai rukyat dan "al-sahra" sebagai hilal, sehingga suhud al-suhur dipahaminya sebagai "ru'yaú al-hilal" dan hisab tidak bisa dikategorikan ke dalam pengertian suhud al-suhur. (Sayyid Sabiq. Th ; 435) Kelanjutan ayat itu, berbicara tentang orang yang sakit atau orang yang sedang bepergian, sehingga, "faman sahida minkum alsahr" dapat juga ditafsirkan sebagai "orang yang berada di tempat (tidak bepergian) dan dalam keadaan sehat". 
Sebaliknya, dalam al-Sunnah, bukan "hisab" yang disebutkan secara eksplisit tetapi rukyat seperti yang terdapat dalam hadits dari 'Abdullah ibn 'Umar dan 'Abdullah ibn 'Abbas yang diri-wayatkan Malik ibn Anas (93-179) dalam kitab-nya Muwauua'.

Surat At-Taubah [9] ayat 36

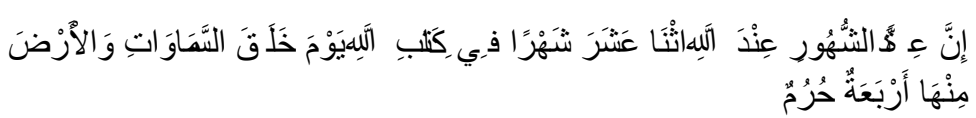

Artinya; Sesungguhnya bilangan bulan pada sisi Allah ialah dua belas bulan dalam ketentuan Allah dieaktu Dia menciptakan langit dan bumi, diantaranya empat bulan yang mulia. Qs. At-Taubah [9]; 36

Sementara menurut astronomi, diketahui ijtima' itu terjadi sebanyak 12 kali dalam satu tahun atau sebulan sekali. Dengan demikian, secara astronomi dapat dikatakan 1 bulan itu adalah dari satu ijtima' ke ijtima' berikutnya, yakni lamanya bulan mengelilingi bumi dari satu fase (manzilah) ke fase berikutnya sampai pada fase yang terakhir sehingga bulan kembali kepada keadaan saat-saat terjadinya ijtima'. Sebelum terjadi ijtima' dapat disebut bulan terlihat semakin mengecil, sedangkan setelah ijtima' bulan terlihat semakin membesar. Keadaan bulan semacam inilah sebagai yang dinyatakan al-Quran

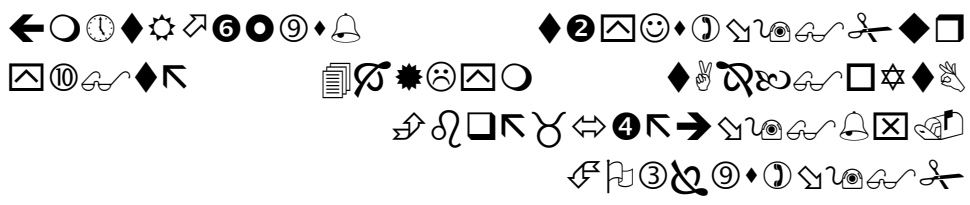

Artinya; Dan Telah kami tetapkan bagi bulan manzilah-manzilah, sehingga (Setelah dia sampai ke manzilah yang terakhir) kembalilah dia sebagai bentuk tandan yang tua ${ }^{20} \ldots$ Qs. Yasin [36] 39

20 Maksudnya: bulan-bulan itu pada Awal bulan, kecil berbentuk sabit, Kemudian sesudah menempati manzilah-manzilah, dia menjadi purnama, Kemudian pada manzilah terakhir kelihatan seperti tandan kering yang melengkung. 
Akan tetapi ijtima' saja, tidak dapat dijadikan patokan penetapan awal bulan baru new moon bukan new month karena secara astronomis perbandingan ukuran piringan bulan dan piringan matahari selalu berubah-ubah. Oleh karena itu diperlukan hal lain sebagai penentu awal bulan baru, sebagai yang diisyaratkan al-Quran

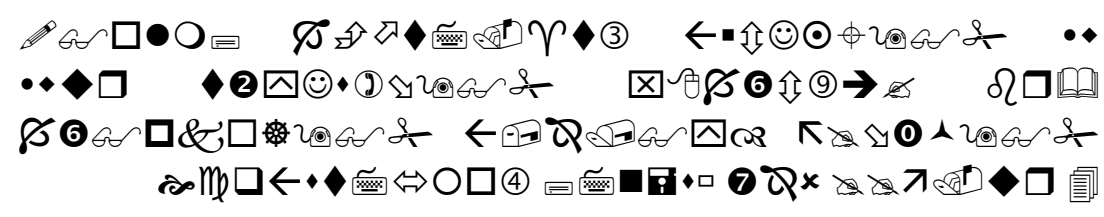

Artinya; Tidaklah mungkin bagi matahari mendapatkan bulan dan malampun tidak dapat mendahului siang. dan masingmasing beredar pada garis edarnya. Qs. Yasin [36] 40.

Sejalan dengan apa yang dinyatakan dalam ayat di atas, bahwa matahari tidak mungkin mengejar bulan, menurut astronomi bahwa gerak semu matahari dalam perjalanan tahunannya jauh lebih lambat bila dibandingkan dengan gerak bulan dalam perjalanan bulanannya yang kedua-duanya sama-sama bergerak dari arah barat ke timur. Bulan menempuh jarak lebih dari $13,2^{0}$, sedangkan matahari kurang dari $0,1^{0}$, karena itu tidak mungkin bagi matahari dapat mengejar bulan.

Jika dihubungkan dengan ayat yang sebelumnya, maka dapat memberikan pengertian bulan baru itu dimulai ketika bulan telah mendahului matahari dalam geraknya masing-masing dari arah barat ke timur. Saat matahari terkejar itulah dalam astronomi disebut ijtima'. Sekalipun ijtima' dapat dipedomani sebagai perpindahan bulan, tetapi sangat sulit untuk diterapkan karena bisa terjadi di sembarang waktu (pagi, siang, sore atau malam hari).

Untuk itu diperlukan "pembatas waktu" yang bisa menyatakan bahwa bulan telah mendahului matahari. Dalam hal ini, sebagai yang diisyaratkan ayat di atas, pembatas waktu itu adalah saat-saat pergantian siang dan malam, yakni saat matahari terbenam. Dengan kata lain apabila pada saat matahari terbenam, bulan telah berada di atas ufuk tanpa memperhitungkan ketinggiannya, maka saat itulah dapat dinyatakan bulan baru (new month).) 


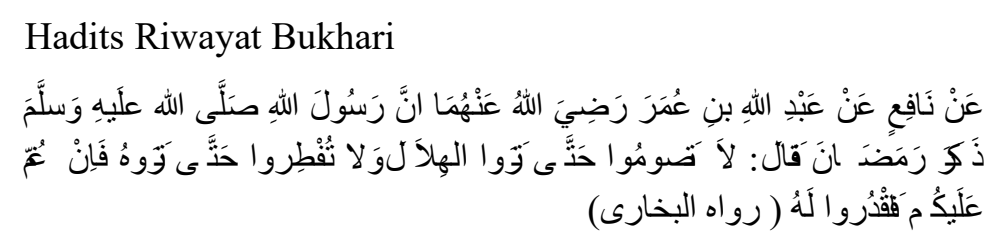

Artinya; Dari Nafi' dari Abdillah bin Umar bahwasannya Rasulullah saw menjelaskan bulan Ramadhan, kemudian Beliau bersabda: janganlah kamu berpuasa sampai kamu melihat hilal, dan janganlah kamu berbuka (berhari raya) sebelum melihat hilal, jika tertutup awan maka perkirakanlah. (HR. Bukhari).

Dengan matan hadits di atas, tidak dapat dipahami sebaliknya (dalalah mafhum mukhalafah) karena ada kata "hatta" (mafhum ghayah); manakala hilal belum terlihat menjadi tidak wajib berpuasa dan berbuka. Karena pemahaman sebaliknya bertentangan dengan penjelasan dari kelanjutan matan tersebut yang secara langsung dan tegas menunjukkan (dalalah manthuq) sekalipun tidak terlihat manakala bilangan bulan sudah tiga puluh (hasil istikmal), tidak bisa tidak kecuali harus berpuasa atau berbuka.

Hadits-hadits di atas, di samping sering disebut-sebut sebagai dasar hukum rukyat, juga sebagai dasar dilakukan istikmal ketika langit berawan atau mendung sehingga mata tidak dapat melihat hilal. Persoalan selanjutnya adalah bagaimana kalau tidak mendung? Adakah alasan untuk istikmal?

Dalam hal ini ada tiga kemungkinan hilal tidak dapat dilihat. Pertama, karena memang hilal belum wujud, negative di bawah ufuk, pada keadaan semacam inilah, baik ahli rukyat maupun hisab sepakat melakukan istikmal bulan yang sedang berlangsung;

Kedua, hilal sudah wujud dan berada pada posisi yang dapat dilihat, tetapi karena berawan menjadi tidak terlihat. Pada keadaan semacam ini pula, berdasar makna dhahir hadits-hadits tersebut, ahli ru'yat melakukan istikmal bulan yang sedang berlangsung, sedang 
ahli hisab yang berkriteria imkan al-ru yat apalagi yang berkriteria wujud al-hilal, berkeyakinan sudah terjadi pergantian bulan.

Ketiga, hilal sudah wujud (positif di atas ufuk) tetapi pada ketinggian yang tidak mungkin dapat dilihat. Pada kondisi semacam ini ahli ru yat dan ahli hisab imkan al-ru yat melakukan istikmal, sedangkan ahli hisab wujud al-hilal berkeyakinan sudah terjadi pergantian bulan baru.

Sebaliknya, perintah untuk menghitung ( $f a^{\prime} u d d u$, faqduru lah), yang oleh jumhur ditafsirkan sebagai istikmal. Akan tetapi, apa yang dilakukan Ibn 'Umar sebagai periwayat pertama hadits " $f a$ in gumma 'alaykum faqduru lah" justru sebaliknya berbeda dengan jumhur dan juga tidak menggunakan perhitungan seperti yang diberitakan oleh Nafi`:

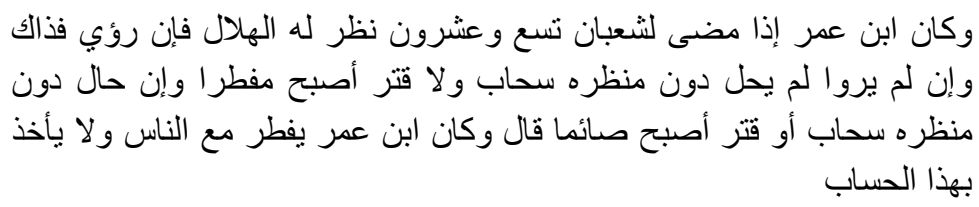

Berbeda dengan jumhur dan Ibn 'Umar, menurut Muhammad ibn Sirrin, dengan adanya perintah faqduru lah tersebut, sebagian tabi'in mengambil pertimbangan (itibar) berdasarkan bintangbintang, fase-fase bulan dan metode hisab. Demikian juga, fuqaha Bashrah, memahaminya dengan memperhatikan fase-fase bulan. (Ibn 'Abd al-Bar, al-Tamhid.th; 350).

Di antara pendapat ulama yang menggunakan rukyat adalah para Imam madzhab empat (Maliki, Hanafi, Syafi'i, dan Hambali) sepakat bahwa awal Ramadlan dan Syawal ditetapkan berdasarkan rukyatul hilal

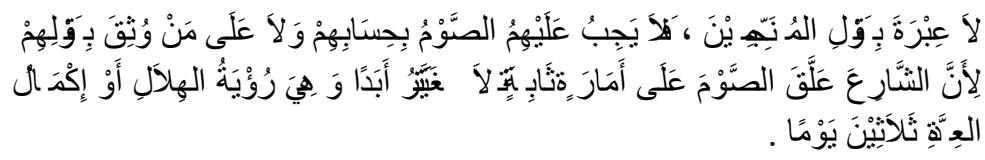

Artinya; Tidak perlu diperhatikan perkataan ahli perbintangan. oleh karena itu, tidak wajib bagi mereka berpuasa berdasarkan hisabnya, dan juga bagi orang yang mempercayainya. Karena pembuat syari'at (Allah SWT) mengkaitkan 
(menggantungkan) puasa pada tanda-tanda yang tetap dan tidak berubah sama sekali, yaitu rukyatul hilal atau menyempurnakan bilangan tiga puluh hari".

An-Nawawi berkata:

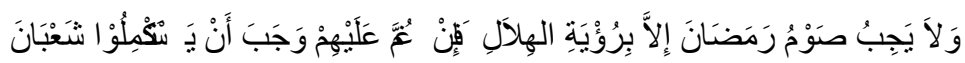

Artinya; Tidak wajib berpuasa Ramadlan kecuali karena rukyatul hilal. Maka apabila hilal tertutup awan bagi mereka maka wajib bagi mereka mentyempurnakan bulan sya'ban (tiga puluh hari). (Al-Ma'mu') Jilid VI, hlm 269.

Ibnu Hajar berkata:

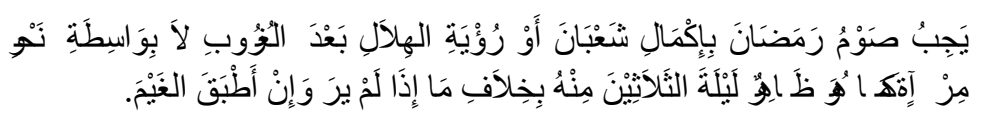

Artinya; Wajib berpuasa Ramadlan karena kesempurnaan bulan sya'ban atau rukyatul hilal sesaat Matahari terbenam tanpa perantara (alat) semecam cermin sebagaimana jelas pada malam tiga puluh sya'ban, berbeda dengan apabila hilal tidak kelihatan walaupun tertutup awan. ${ }^{21}$

Imam Ar-Romli berkata:

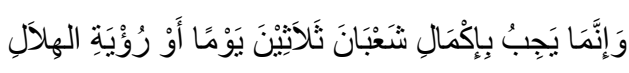

Artinya:"Berpuasa itu wajib hanya karena kesempurnaan sya'ban tiga puluh hari atau ru'yatul hilah". ${ }^{22}$

Madzhab Empat:

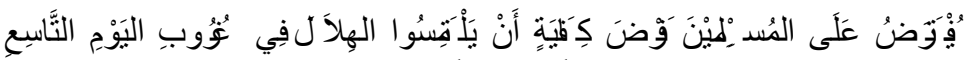

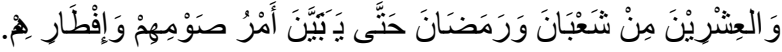

Artinya; Diwajibkan bagi kaum muslimin sebagai fardhu kifayah untuk mencari hilal pada saat terbenamnya matahari

${ }^{21}$ Ibnu Hajar alhaitami, Tuhfatul Muhtaj, jilid III, hal. 133

${ }^{22}$ Syamsuddin Muhammad bin Abil‘Abbas Ahmad bin Hamzah Ibnu Syihabuddin Ar-Ramli, Nihayatul Muhtaj, Jilid III h. 147. 
tanggal 29 Sya'ban dan Romadhon sehingga jelas masalah berpuasa dan berbuka mereka. ${ }^{23}$

Imam Ba'lawi

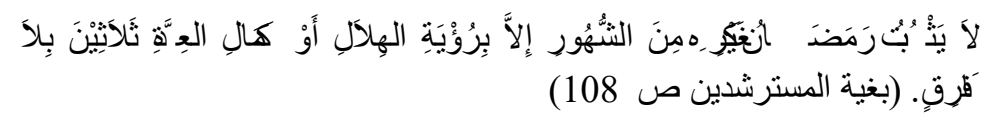

Artinya; Tidak bisa ditetapkan Ramadhan itu, seperti bulan-bulan yang lain, kecuali dengan rukyatul hilal atau menyempurnakan (istikmal) bilangan tiga puluh tanpa pebedaan. ${ }^{24}$

Imam Bakhit Al-Muthi'i

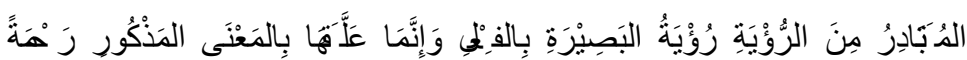

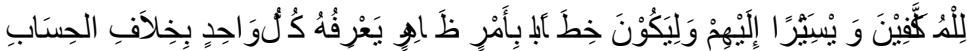

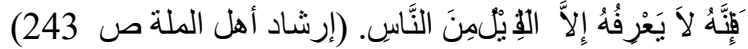

Artinya; Pengertian rukyat yang cepat dipahami ialah melihat bil fi'li (benar-benar dengan mata). Dikaitkannya dengan pengertian tersebut hanyalah untuk menjadi rahmat dan memudahkan kepada orang-orang mukallaf, dan agar menjadi khitab (ucapan) dengan suatu hal yang nyata yang diketahui oleh setiap orang. Berbeda dengan hisab, karena ia hanya diketahui oleh orang sedikit. ${ }^{25}$

\section{Penutup}

Dari uraian di atas, maka dapat diambil kesimpulan sebagai bagian dalam penutup ini adalah terkait dengan hisab rukyat ulama sepakat bahwa yang diperhitungkan dalam penentuan bulan Ramadan ialah rukyatul hilal. Dan mereka sepakat bahwa bila tampak hilal setelah lingsir matahari dan tidak diketahui bahwa telah tampak kemarin, maka bulan Ramadan mulai dari hari kedua itu.

\footnotetext{
${ }^{23}$ Abdurrahman al-Jazairi, Al-Fiqih Ala Madhahibil Alba', Jilid I hal. 551.

${ }^{24}$ Abdurrahman bin Muhammad bin Husain bin Umar al-Masyhur, Bughyatul Mustarsyidin, hal.. 108

${ }^{25}$ Irsyadu Ahlil Millah, hal. 243
} 
Imam Syafi'i, ulama besar Ibnu Hajar al Haitami dan Ibnu Rusyd al Andalusi, pada suatu kesempatan dan versi yang berbeda memberi pandangan bahwa : Madzhabuna al shawab yahtamil al khathaa wa madzhab ghairina al khathaa yahtamil al shawab. "Pendapat kami benar, tapi mengandung kesalahan dan pendapat selain kami salah, tetapi mengandung kebenaran". Selain itu Ulama besar Muhammad Rasyid Ridlo membuat khittah pedoman perjuangannya, dengan kaidah: Nata'awan fima ittafaqna 'alai wa ya'dzir ba'dluna ba'dlan fima ikhtalafna fihi. "Bekerjasama dalam masalah yang kita sepakati dan saling toleransi dalam masalah yang kita perselisihkan.

\section{Referensi}

Abd al-Rauf al-Manawi, 1356 H, Fayce al-Qadir Saro al-Jami ' alEagir. Misir: Al-Maktabaú al-Tijariyaú al-Kubra.

Al-Qadli, Samir, 1995, Tatsbitu Ahlil Iman fil I'timadi lishshaumi ala Rukyati Hilali Ramadlan au Istikmal Tsalatsina min Sya'ban, Amerika Serikat: Dairotuddirosah al-Islamiyyah.

Amin, Makruf, 2008, Fatwa dalam Sistem Hukum Islam, Jakarta: Elsas.

Biek, Muhammad al-Khudhari, 2007, Ushul Fiqh, Jakarta: Pustaka Amani.

Dirjen Bimas Islam Kementerian Agama RI, 2010, Almanak Hisab Rukyah.

Ditjen Bimas Islam dan Penyelenggaraan Ibadah Haji, Selayang Pandang Hisab Rukyah, 2004

Hambali, Slamet dan Ahmad Izzuddin, 30 Desember 1997, "Awal Ramadhan 1418 H dan Validitas Ilmu Hisab Rukyah”, dalam Wawasan,

Hambali, Slamet, Ilmu Falak II, Semarang: jes_sarung, 2009 
Erlangga.

Izzuddin, Ahmad, , 2007, Fiqih Hisab Rukyah, Jakarta:

Khallaf, Abdul Wahhab, , 2003, Ilmu Ushul Figh, Jakarta: Pustaka Amani.

Koto, Alaiddin, , 2004, Ilmu Fiqh dan Ushul Fiqh, Jakarta: PT Rajagrafindo Persada.

Lajnah Falakiyyah PBNU, 2006, Pedoman Rukyat dan Hisab NU, Jakarta: LFPBNU.

Machfudz, Sahal, Insklopedi Ijmak, Jakarta: Pustaka Firdaus, 2006.

Mahmud, Nizar, al-Ma'ayir al-Fiqhiyyah wa al-Falakiyyah, Mesir: Darul Basyair al-Islamiyyah.

Muhammad ibn 'Ali al-Sawkani, 1973 , Nayl al-Awùar Saro Muntaqa al-Aóbar, Bayrut: Dar al-Jayl.

Rifa'i, Moh., , 1973, Ushul Fiqh, Bandung: PT Alma'arif.

Saebani, Beni Ahmad, 2009, Ilmu Usul Fiqh, Bandung: CV Pustaka Setia.

Syafi'i, Rahmat, 1999, Ilmu Ushul Fiqh, Bandung: CV Pustaka Setia.

Syarifuddin, Amir, , 2007, Ushul Fiqh, Jilid 1, Jakarta; Logos.

Taqiy al-Din Abu al-Fath ibn Daqiq al-'id, t.th., Ihkam al-Ahkam Sarh 'Umdat al-Ahkam, Bayrut: Dar al-Kutub al-'Ilmiyau.

* Dosen Ilmu Falak IAIN Syaikh Abdurrahman Siddik Bangka Belitung 